\title{
Análisis de PCR-RFLP del gen de leptina y su asociación con características de la leche en ganado nativo (Bos indicus) de Irán
}

\author{
PCR-RFLP analysis of leptin gene and its association with \\ milk traits in native cattle of Iran (Bos indicus)
}

\author{
Mojtaba Rezaeia, Seyed Ziaeddin Mirhosseinia, Navid Ghavi Hossein-Zadeha
}

\section{RESUMEN}

Se utilizó una muestra ganadera experimental para la caracterización de los genes y las frecuencias genotípicas y evaluar la asociación entre los polimorfismos de longitud del fragmento de restricción BsaAI en el gen de leptina y las características lácteas. Se recolectaron muestras de sangre de 390 vacas proporcionadas por el censo ganadero de la provincia de Guilán en Irán. La extracción de ADN genómico se basó en el método modificado de precipitación salina. El fragmento de 522 bp que comprende la región parcial del exón 3 e intrón 2 del locus del gen de leptina se amplificó mediante PCR-RFLP e iniciadores específicos. La digestión del fragmento amplificado con la enzima de restricción BsaAI reveló dos alelos de A y B con frecuencias de 0.447 y 0.553 , y tres genotipos de AA, AB, BB con frecuencias de $0.185,0.526$ y 0.289 en la población estudiada, respectivamente. El resultado del contenido de polimorfismo fue 0.372 y para heterocigosis 0.526 . Los resultados demostraron que la población estudiada estaba en equilibrio Hardy-Weinberg. El análisis estadístico indicó que el polimorfismo LEP-BsaAI tiene un efecto significativo en la producción de leche, porcentaje de grasa y proteína de la leche $(P<0.01)$. Animales portadores del genotipo heterocigoto (AB) produjeron 1.17 y $0.7 \mathrm{~kg} / \mathrm{d}$ más leche que los animales homocigotos AA y BB, respectivamente. Los animales con el genotipo AA tuvieron mayor grasa $(0.28 \%)$ y porcentaje de proteína $(0.17 \%)$ que el genotipo AB. Tales resultados pueden utilizarse como criterios para facilitar la selección genética en los programas de cría animal.

PALABRAS ClaVe: DNA, Polimorfismo, Producción de leche, RFLP.

\begin{abstract}
An experimental cattle population was screened for characterization of gene and genotypic frequencies, and association between BsaAI restriction fragment length polymorphisms in the leptin gene and milk traits. Blood samples were collected from 390 cows provided by census herds of Guilan province in Iran. The extraction of genomic DNA was based on modified Salting Out method. The 522 bp fragment comprising the partial intron 2 and exon 3 region of leptin gene locus was amplified using PCR-RFLP and specific primers. Digestion of amplified fragment with restriction enzyme BsaAI revealed two alleles of $A$ and $B$ with frequencies of 0.447 and 0.553 and three genotypes of $A A$, AB and $B B$ with frequencies of $0.185,0.526$ and 0.289 in the studied population, respectively. Polymorphism information content was $\mathbf{0 . 3 7 2}$ and heterozygosity was $\mathbf{0 . 5 2 6}$. The chi-square test results showed that the studied population was in Hardy-Weinberg equilibrium. The impact of Leptin genotypes on milk traits was conducted based on a linear model of SAS software using least squares means methods. Statistical analyses indicated that the LEP-BsaAI polymorphism has a significant effect on milk yield, milk fat and protein percentage $(P<0.01)$. Animals carrying the heterozygous genotype (AB) produced 1.17 and $0.7 \mathrm{~kg} / \mathrm{d}$ more milk than the homozygous AA and BB animals, respectively. Animals with the AA genotype had higher fat $(0.28 \%)$ and protein $(0.17 \%)$ percentage than AB genotype. Such results may be used as a selection criterion to facilitate genetic selection in animal breeding programs.
\end{abstract}

KEY WORDS: DNA polymorphism, Local cattle, Milk yield, RFLP.

Recibido el 19 de junio de 2014. Aceptado el 28 de julio de 2014

a Department of Animal Science, Faculty of Agricultural Sciences, University of Guilan, Rasht, Iran, Tel) +989119661711, mojtaba.rezaee1@gmail.com. Correspondencia al primer autor. 


\section{INTRODUCCION}

Variaciones a nivel de ADN contribuyen a la caracterización genética de las poblaciones ganaderas, y esto puede ayudar a identificar posibles eventos de hibridación y últimas tendencias evolutivas. En ganadería, tales variaciones en el ADN también pueden estar asociadas con, o ligadas a los rasgos económicos, que son gobernados por muchos genes, cada uno con un pequeño efecto(1). Esos genes principales suelen estar involucrados en la biología de un rasgo, y son los genes candidatos para identificar marcadores(2). También existe la posibilidad de que genes mayores puedan estar relacionados con algunos loci de rasgos cuantitativos (QTL), contribuyendo a la mayor parte de la variación en los rasgos.

La leptina es una hormona peptídica de $16 \mathrm{kDa}$ que se sintetiza principalmente en el tejido adiposo y afecta diversos procesos en el cuerpo. Está íntimamente involucrada en el crecimiento y metabolismo de los animales, desempeña un papel importante en la regulación del consumo de alimento, metabolismo de energía, crecimiento, producción de leche y reproducción del ganado $(3,4)$. Por lo tanto, el gen de leptina es un candidato potencial para estudios de QTL. En Bos indicus el gen de leptina (LEP) está situado en el cromosoma somático 4 (número de adhesión: Y11369). Este gen fue completamente secuenciado y consta de tres exones y dos intrones, de los cuales sólo dos exones se traducen en proteina(5).

En el ganado lechero, los genes asociados al desarrollo, crecimiento y función de la glándula mamaria son genes candidatos para características de producción de leche. En consecuencia, el gen también puede afectar a rasgos tales como consumo de alimento(6), producción y composición de leche $(7,8,9,10)$, producción de carne en canal y calidad cárnica $(11,12,13)$ y comportamiento reproductivo(14,15), que son importantes para la cría de ganado. Puesto que la leptina puede desempeñar un papel importante en los procesos que ocurren durante

\section{INTRODUCTION}

Variations at DNA level contribute to the genetic characterization of livestock populations and this may help to identify possible hybridization events and past evolutionary trends. In livestock, such variations in DNA may also be associated with, or linked to, economic traits, which are governed by many genes each having a small effect $(1)$. Those major genes being usually involved in the biology of a trait and they are the candidate genes for marker identification(2). There is also the possibility that major genes may be linked with some quantitative trait loci (QTL) contributing to a major part of the variation in traits.

Leptin is a $16 \mathrm{kDa}$ peptide hormone which is synthesized predominantly in the adipose tissue and affects a number of processes in the body. It is involved intricately in the growth and metabolism of animals, which plays an important role in the regulation of feed intake, energy metabolism, growth, milk production and reproduction of cattle $(3,4)$. Therefore, the leptin gene is a potential candidate gene for QTL studies. The leptin (LEP) gene is located on Bos indicus autosome chromosome 4 (Accession No: Y11369). This gene was completely sequenced and consists of three exons and two introns of which only two exons are translated into protein(5).

In dairy cattle, genes associated with mammary gland growth, development and function are candidate genes for milk production traits. Consequently, the gene may also affect traits such as feed intake(6), milk production and composition $(7,8,9,10)$, meat production, carcass and meat quality $(11,12,13)$ and reproductive performance $(14,15)$ which are important in terms of breeding. Since leptin may play an important role in the processes occurring during lactation in dairy cows, the utilization of this gene as a candidate or genetic marker in selection programs for production traits in native cattle could be a promising option. The objectives of this study were characterization of gene and 
la lactancia en vacas lecheras, la utilización de este gen como un candidato o un marcador genético en programas de selección para características de producción en el ganado nativo, podría ser una opción prometedora. Los objetivos de este estudio fueron la caracterización del gen y las frecuencias genotípicas, y evaluar la asociación entre BsaAI-RFLP en el gen de leptina con rendimiento de características de la leche de ganado criollo en Guilán, Irán.

\section{MATERIALES Y MÉTODOS}

Se recolectaron muestras de sangre de la vena yugular de 390 vacas nativas Bos indicus escogidas al azar de cuatro regiones (Fouman= 162, Rasht $=98$, Astaneh $=85$ y Lahijan= 45) pertenecientes a los hatos de la provincia de Guilán en Irán, utilizando tubos vacutainer con anticoagulante EDTA. Las muestras se transportaron inmediatamente al laboratorio en un congelador y almacenadas a $-20^{\circ} \mathrm{C}$ para su posterior extracción de ADN. El ADN genómico se extrajo de leucocitos sanguíneos mediante la optimización del método modificado de precipitación salina(16). Se evaluó la calidad y cantidad de muestras extraídas por electroforesis en gel de agarosa al $0.8 \%$ y el método de espectrofotometría, que confirmaron la concentración adecuada y la pureza de las muestras de ADN para la reacción en cadena de polimerasa (PCR).

Un fragmento de 522 bp compuesto parcialmente por intrón 2 y el exón 3 del gen genotypic frequencies, and evaluate the association between BsaAI-RFLP in the leptin gene with performance of milk traits of Guilan native cattle in Iran.

\section{MATERIALS AND METHODS}

Whole blood samples were collected from the jugular vein of 390 Guilan native cows (Bos indicus) chosen randomly from four regions (Fouman $=162$, Rasht $=98$, Astaneh $=85$ and Lahijan=45) belonging to the herds of Guilan province in Iran using EDTA-anticoagulated vacutainer tubes. The samples were transported immediately to the laboratory in a freezer and stored at $-20{ }^{\circ} \mathrm{C}$ for further DNA extraction. Genomic DNA was extracted from blood leukocyte cells using the modified salting out method(16). Quality and quantity of extracted samples was assessed by electrophoresis on $0.8 \%$ agarose gel and using spectrophotometry method that confirmed appropriate concentration and purity of DNA samples for polymerase chain reaction (PCR).

A 522 bp fragment comprising the partial intron 2 and exon 3 of leptin gene was amplified by PCR using specific primers (Table 1), as suggested by Lien et $a(17)$ who described for the first time the substitution of guanine $(G)$ to adenine (A) in intron 2 of the leptin gene of Norwegian cattle. Amplification reactions were performed in a final volume of $25 \mu \mathrm{l}$ which final concentration was containing 50-100 ng of genomic DNA, 1x PCR Buffer, 10 pmol of each

Cuadro 1. Secuencia de iniciadores, posición y tamaño del fregmento del gen de leptina utilizando análisis de PCRRFLP en ganado criollo de Guilán, Iran

Table 1. Primer sequence, position and PCR product size used in RFLP analysis of the leptin gene in Guian native cattle of Iran

\begin{tabular}{llccccc}
\hline $\begin{array}{l}\text { Amplified } \\
\text { region }\end{array}$ & $\begin{array}{l}\text { Primer sequence }\left(5^{\prime}-3^{\prime}\right) \\
(\text { Lien et al.)(17) }\end{array}$ & $\begin{array}{c}\text { Nucleotide } \\
\text { change }\end{array}$ & $\begin{array}{c}\text { Restriction } \\
\text { enzyme }\end{array}$ & $\begin{array}{c}\text { Fragment } \\
\text { size }\end{array}$ & $\begin{array}{c}\text { Analysis } \\
\text { method }\end{array}$ & $\begin{array}{c}\text { GenBank } \\
\text { accession No. }\end{array}$ \\
\hline $\begin{array}{l}\text { partial intron 2 } \\
\text { \& exon 3 }\end{array}$ & $\begin{array}{l}\text { GTC TGG AGG CAA AGG } \\
\text { GCA GAG TCCA CCA CCT }\end{array}$ & G 1620 A & BsaA I (Ppu21 I) & $522 \mathrm{bp}$ & RFLP & Y11369 \\
\hline
\end{tabular}


leptina se amplificó por PCR usando iniciadores específicos (Cuadro 1), según lo sugerido por Lien et $a(17)$ quienes describieron por primera vez la sustitución de la guanina (G) por adenina (A) en el intrón 2 del gen de leptina de ganado Noruego. Las reacciones de amplificación se realizaron en un volumen final de $25 \mu \mathrm{l}$ con una concentración final de 50-100 ng de ADN genómico, 1x amortiguador PCR, 10 pmol de cada iniciador, $100 \mu \mathrm{M}$ dNTP Mix, $1.5 \mathrm{mM} \mathrm{MgCl}$, 1 unidad taq de ADN polimerasa y ddH2O. El perfil térmico del proceso consistió en un paso de desnaturalización inicial por 3 min a $94^{\circ} \mathrm{C}$, seguido de 35 ciclos (desnaturalización a $94^{\circ} \mathrm{C}$ por $30 \mathrm{seg}$, iniciador recalentado a $62{ }^{\circ} \mathrm{C}$ durante $35 \mathrm{seg}$ y extensión a $72{ }^{\circ} \mathrm{C}$ por $1 \mathrm{~min}$ ) y una extensión final a $72{ }^{\circ} \mathrm{C}$ durante $10 \mathrm{~min}$. Los productos de PCR se separaron y se reconocieron por electroforesis en gel de agarosa al $1.5 \%$ teñido con bromuro de etidio. Los genotipos del gen de leptina se determinaron mediante la técnica de PCR-RFLP. El estudio del polimorfismo del gen de leptina y la digestión de los productos de PCR se realizaron con la enzima de restricción BsaAI (Ppu21I) que identifica secuencias 5' AC"!GT 3'. Fragmentos amplificados fueron digeridos por la enzima $B s a A I$ a $30{ }^{\circ} \mathrm{C}$ durante $3 \mathrm{~h}$ con la siguiente mezcla reactiva: $8 \mu \mathrm{l}$ del producto de PCR, $3 \mu \mathrm{l}$ del amortiguador de digestión $10 \mathrm{X}, 5 \mathrm{U}(0.5 \mu \mathrm{l})$ enzima de restricción y $8 \mu \mathrm{l}$ de agua desionizada. Los productos de digestión se separaron por electroforesis horizontal (70 voltios, $110 \mathrm{~min}$ ) en gel de agarosa al $3 \%$, teñido con bromuro de etidio, y el tamaño de los fragmentos digeridos se reconoció por marcadores pBR322/BsuRI de ADN; los genotipos se determinaron basados en la diferencia de tamaño de los fragmentos en el gel.

En este estudio se utilizaron registros diarios de 390 vacas con diferentes días de lactación en el hato del censo recogido y verificado por la organización agrícola de Guilán. En el Cuadro 2 se presenta el resumen estadístico de las características de la leche en la población estudiada. primer, $100 \mu \mathrm{M}$ dNTP Mix, $1.5 \mathrm{mM} \mathrm{MgCl} 2,1$ unit of Taq DNA polymerase and $\mathrm{dd}_{2} \mathrm{O}$. The thermal cycling profile consisted of an initial denaturation step for $3 \mathrm{~min}$ at $94{ }^{\circ} \mathrm{C}$, followed by 35 cycles (denaturation at $94^{\circ} \mathrm{C}$ for $30 \mathrm{sec}$, primer annealing at $62{ }^{\circ} \mathrm{C}$ for $35 \mathrm{sec}$ and extension at $72{ }^{\circ} \mathrm{C}$ for $1 \mathrm{~min}$ ) and a final extension at $72{ }^{\circ} \mathrm{C}$ for $10 \mathrm{~min}$. PCR products were separated and recognized by electrophoresis on $1.5 \%$ agarose gel stained with ethidium bromide. Genotypes of leptin gene were determined by PCR-RFLP technique. Study of leptin gene polymorphism and digestion of PCR products was conducted by BsaAI (Ppu21I) restriction enzyme that identifies 5' AC'!GT 3' sequences. Amplified fragments were digested by BsaAI enzyme at $30^{\circ} \mathrm{C}$ for $3 \mathrm{~h}$ with the following reaction mixture: $8 \mu$ l PCR product, 3 $\mu$ l digestion Buffer 10X, $5 \cup(0.5 \mu l)$ restriction enzyme and $8 \mu$ deionized water. The digestion products were separated by horizontal electrophoresis (70 volts, $110 \mathrm{~min}$ ) in $3 \%$ agarose gels stained with ethidium bromide and digested fragments size was recognized by pBR322/BsuRI DNA markers and genotypes were determined based on the difference in fragments' size on the gel.

Test-day records of 390 Guilan native cows with different days in milk in the census herd of Guilan province which were verified and collected by the Agricultural Organization of Guilan province in Iran were used in this study. Summary statistics for milk traits in the studied population are presented in Table 2.

Cuadro 2. Datos estadísticos para producción de leche y porcentajes de grasa y proteina

Table 2. Descriptive statistics for milk yield, fat and protein percentages of milk

\begin{tabular}{lcccc}
\hline Traits & $\mathrm{N}$ & Mean & SD & CV (\%) \\
\hline Milk yield, kg & 4787 & 3.21 & 1.13 & 35.20 \\
Fat, \% & 4688 & 3.22 & 0.80 & 24.84 \\
Protein, \% & 4688 & 3.19 & 0.66 & 20.69 \\
\hline
\end{tabular}

$\mathrm{SD}=$ Standard deviation; $\mathrm{CV}=$ Coefficient of variation. 
Las frecuencias de alelos y genotipos dentro de las poblaciones y la prueba de Ji cuadrada $\left(\mathrm{X}^{2}\right)$ se realizaron utilizando Pop Gene V. 1.32(18). En el modelo lineal general (GLM) se utilizó el procedimiento de SAS 9.1(19) para probar las asociaciones entre diferentes genotipos $y$ componentes de la leche; la diferencia entre las medias de cuadrados mínimos de las características estudiadas para los genotipos del gen de leptina se compararon usando el método de Tukey-Kramer. El siguiente modelo estadístico se utilizó para evaluar la asociación entre genotipos de leptina y los componentes lácteos:

$$
\mathrm{Y}_{\mathrm{ijklmno}}=\mu+\mathrm{G}_{\mathrm{i}}+\mathrm{R}_{\mathrm{j}}+\mathrm{P}_{\mathrm{k}}+\mathrm{YC}_{1}+\mathrm{SC}_{\mathrm{m}}+\mathrm{b}_{1 \mathrm{n}}\left(\text { Age }_{\mathrm{n}}-\overline{\mathrm{Age}}\right)+\mathrm{e}_{\mathrm{ijklmno}}
$$

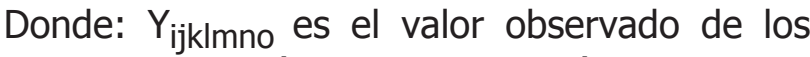
componentes lácteos (producción de leche, porcentajes de grasa y proteína); $\mu$ es la media general de la población para los diferentes parámetros; $G_{i}$ es el efecto fijo del genotipo leptina ( $i=1,2$ and 3 ); $R_{j}$ es el efecto fijo de región ( $j=1,2$ and 3 ); $P_{k}$ es el efecto fijo de paridad $(\mathrm{k}=1,2, \ldots$ and 7$) ; \mathrm{YC}_{\mathrm{l}}$ es el efecto fijo de año de parto ( $I=2006-2012) ; S_{m}$ es el efecto fijo para época de parto $(m=1,2,3 \mathrm{y}$ 4); $b_{1 n}$ es el coeficiente de regresión lineal de componentes lácteos sobre edad al parto; $\mathrm{Age}_{\mathrm{n}}$ es el efecto de covarianza lineal de la edad al parto ( $0=30-140$ meses); $\overline{\text { Age }}$ es el promedio de edad al parto de la población; y $\mathrm{e}_{\mathrm{ijk} \text { kmno }}$ es el efecto aleatorio residual.

\section{RESULTADOS Y DISCUSIÓN}

La extracción de ADN de la sangre en todas las muestras se completó exitosamente. Los resultados de electroforesis mostraron que la calidad del ADN extraído fue apropiada para PCR. La electroforesis de los productos PCR en gel de agarosa al $1.5 \%$ demostró que los iniciadores diseñados actuaron bien y produjeron fragmentos específicos para el gen leptina de 522 bp de longitud. La digestión del fragmento de 522 bp del locus del gen leptina con la enzima de restricción $B s a A I$ causó dos patrones
Frequencies of alleles and genotypes within the populations and Chi-square test $\left(\mathrm{X}^{2}\right)$ were performed using Pop Gene V. 1.32(18). The general linear model (GLM) procedure of SAS 9.1(19) was used to test the associations among different genotypes and milk traits of cows and also the difference between least squares means of studied traits for leptin gene genotypes were compared using Tukey-Kramer's method. The following statistical model was used to evaluate association between leptin genotypes and milk traits in Guilan native cows:

$$
\mathrm{Y}_{\mathrm{ijklmno}}=\mu+\mathrm{G}_{\mathrm{i}}+\mathrm{R}_{\mathrm{j}}+\mathrm{P}_{\mathrm{k}}+\mathrm{YC}_{1}+\mathrm{SC}_{\mathrm{m}}+\mathrm{b}_{\mathrm{ln}}\left(\mathrm{Age}_{\mathrm{n}}-\overline{\mathrm{Age}}\right)+\mathrm{e}_{\mathrm{ijklmno}}
$$

Where: $Y_{i j k l m n o}$ is the observed value for milk traits (milk yield, milk fat and protein percentages); $\mu$ is the overall mean of populations for different traits; $G_{i}$ is the fixed effect of leptin genotype ( $i=1,2$ and 3 ); $R_{j}$ is the fixed effect of region ( $j=1,2$ and 3$) ; P_{k}$ is the fixed effect of parity ( $k=1,2, \ldots$ and 7$)$; $\mathrm{YC}_{\mathrm{I}}$ is the fixed effect of year of calving ( $\mathrm{I}=$ 2006-2012); $\mathrm{SC}_{\mathrm{m}}$ is the fixed effect of season of calving ( $m=1,2,3$ and 4$) ; b_{1 n}$ is the linear regression coefficient of milk traits on age at calving $\mathrm{Age}_{\mathrm{n}}$ is the linear covariate effect of age at calving ( $0=30-140$, month); $\overline{\text { Age }}$ is average of age at calving in population; and $\mathrm{e}_{\mathrm{ijklmno}}$ is the random residual effect.

\section{RESULTS AND DISCUSSION}

DNA extraction from blood in all samples was completed successfully. Electrophoresis results showed that the quality of extracted DNA is appropriate for PCR. PCR products by electrophoresis on $1.5 \%$ agarose gel showed that designed primers acted well and produced specific fragments for the leptin gene of 522 bp in length. Digestion of the 522 bp fragment from leptin gene locus with BsaAI restriction enzyme caused two digestion patterns, including pattern A, an intact 522 bp fragment (without enzyme cutting site), and pattern $B$ that exhibited 441 and 81 bp fragments. The results 
de digestión, incluyendo el patrón $A$, un fragmento intacto de 522 bp (sin sitio de corte de la enzima) y un patrón B que exhibió fragmentos de 441 y $81 \mathrm{bp}$. Los resultados del presente estudio en la digestión de la enzima y longitud del fragmento observado concuerdan con los del ganado Noruego(17) y el Indio Bos indicus y Bos taurus(20). La Figura 1 muestra la separación de fragmentos 522, 441 y 81 bp y el patrón de restricción de tres genotipos $A A$, $A B$ y $B B$ sobre la digestión del locus leptina usando la enzima de restricción BsaAI.

En el Cuadro 3 se presentan las frecuencias genotípicas y alélicas para el polimorfismo BsaAIRFLP del gen leptina. Los resultados indicaron que la frecuencia del alelo B (0.553) fue la más alta en las cuatro regiones, mientras que la más grande y la más baja frecuencia genotípica fueron para $A B(0.526)$ y $A A(0.185)$.

La prueba de $X^{2} \quad(2.77<5.99) \quad$ confirmó el equilibrio de Hardy-Weinberg en las poblaciones estudiadas para el locus de leptina. Esto significa que existen características de una población en equilibrio como la falta de selección, migración, mutación y derivación genética. Las posibles razones pueden ser debidas a los apareamientos aleatorios y a la falta de intercambio genético con otras poblaciones. of the present study in enzyme digestion and observed fragment length agreed with those in Norwegian cattle(17) and in Indian Bos indicus and Bos taurus cattle(20). Figure 1 shows separation of 522, 441 and 81 bp fragments and restriction pattern of three genotypes $A A$, $A B$ and $B B$ upon digestion of the leptin locus using BsaAI restriction enzyme.

Figure 1. Productos del PCR del gen de leptina diferidos con la enzima BsaAl a $3 \%$ de gel de agarosa teñido con bromuro de etidio

Figure 1. PCR products of the leptin gene digested by BsaAl on $3 \%$ agarose gel, stained by ethidium bromide

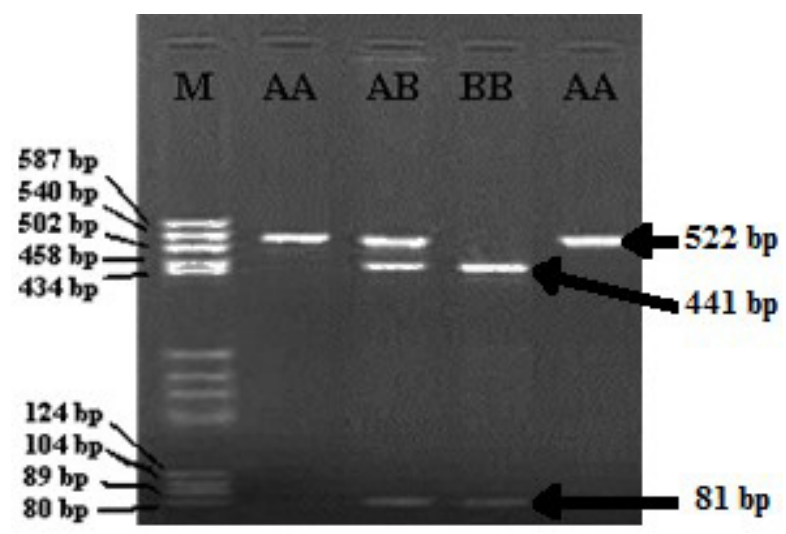

Lane $M$ is a DNA size marker (pBR322/BsuRI), Lanes 2 and 5 are AA genotype (522 bp), Lane 3 is AB genotype (522, 441 and $81 \mathrm{bp}$ ) and Lane 4 is BB genotype (441 and $81 \mathrm{bp}$ ).

Cuadro 3. Frequencias de genotipos y alelos observados en el gene de leptina (BsaAl- RFLP), polimorfismo (PIC) y $X^{2}$

Table 3. Frequencies of genotypes and alleles observed in the leptin gene (BsaAl- RFLP), polimorphysm (PIC) and $X^{2}$ test

\begin{tabular}{|c|c|c|c|c|c|c|c|c|}
\hline \multirow[b]{2}{*}{ Region } & \multirow[b]{2}{*}{ No. of cows } & \multicolumn{2}{|c|}{ Allele } & \multicolumn{3}{|c|}{ Genotype } & \multirow[b]{2}{*}{ PIC } & \multirow[b]{2}{*}{$x^{2}$} \\
\hline & & $A$ & B & AA & $A B$ & BB & & \\
\hline Fouman & 162 & 0.47 & 0.53 & 0.20 & 0.55 & 0.25 & 0.374 & 1.59 \\
\hline Rasht & 98 & 0.46 & 0.54 & 0.19 & 0.53 & 0.28 & 0.373 & 0.39 \\
\hline Astaneh & 85 & 0.42 & 0.58 & 0.18 & 0.48 & 0.34 & 0.368 & 0.02 \\
\hline Lahijan & 45 & 0.39 & 0.61 & 0.13 & 0.51 & 0.36 & 0.363 & 0.19 \\
\hline Total & 390 & 0.447 & 0.553 & 0.185 & 0.526 & 0.289 & 0.372 & 2.77 \\
\hline $\mathrm{SE} \pm$ & - & 0.037 & 0.037 & 0.031 & 0.030 & 0.051 & 0.005 & 0.711 \\
\hline
\end{tabular}

$\mathrm{PIC}=$ Polymorphic information content; $\mathrm{X}^{2}=$ chi-square value, $(P>0.05)$. 
En el Cuadro 4 se muestran los efectos de los genotipos para el gen de leptina sobre las características de la leche. La comparación de medias de cuadrados mínimos de diferentes genotipos de características de la leche mostraron diferencias significativas entre los genotipos $(P<0.01)$. Según los resultados actuales, una vaca con genotipo $A B$ se asoció con mayor producción de leche y menos porcentaje de grasa y proteína en comparación a las vacas de otros genotipos. Las razones pueden ser debidas a la correlación negativa entre la producción de leche, y porcentajes de grasa y proteína en el ganado. De hecho, estos rasgos son sensibles a la selección, y la selección para aumentar la producción de leche disminuirá el porcentaje de grasa de la leche(21). Además, el genotipo $A B$ resultó en mayor producción de leche con 1.17 y $0.7 \mathrm{~kg} / \mathrm{d}$ de los genotipos $A A$ y $B B$, respectivamente, mientras que el genotipo AA tenía más porcentaje de grasa y proteína que los otros genotipos (Cuadro 4; $P<0.01$ ). Por otra parte, no hubo ninguna diferencia significativa entre genotipos $A B$ y $B B$ para el porcentaje de grasa y entre los genotipos $A A$ y BB para el porcentaje de proteína $(P>0.05)$.

Los resultados del estudio fueron acordes con los informes más publicados sobre los efectos de genotipos de la leptina en características productivas. Consistente con los resultados del presente estudio, se demostraron tendencias y asociaciones positivas entre diferentes
Genotypic and allelic frequencies for the BsaAIRFLP polymorphism of leptin gene are presented in Table 3. Results indicated that B allele frequency (0.553) was the highest in all four regions, whereas the greatest and the lowest genotypic frequencies were for $A B(0.526)$ and AA (0.185), respectively.

The $X^{2}$ test $(2.77<5.99)$ confirmed the HardyWeinberg equilibrium in the studied populations for leptin locus. This means that in target population, there are conditions for the population in equilibrium such as lack of selection, migration, mutation and genetic drift. The possible reasons may be due to random matings and the lack of genetic exchange with other populations.

The effects of leptin gene genotypes on milk traits in Guilan native cows are shown in Table 4. The comparison of least squares means of various genotypes for milk traits in Guilan native cows showed significant differences between genotypes $(P<0.01)$. According to the current results, a cow with $A B$ genotype was associated with higher milk yield and less fat and protein percentages compared to cows of other genotypes. The reasons may be due to the negative correlation between milk yield and fat and protein percentages in cattle. Indeed, these traits are sensitive to selection, and selection for enhancing milk production will decrease milk fat percentage(21). Also, $A B$ genotype resulted in higher milk yield as 1.17 and $0.7 \mathrm{~kg} / \mathrm{d}$ than

Cuadro 4. Medias de cuadrados mínimos de varios genotipos para características de la leche en ganado nativo de Guilan (Bos indicus)

Table 4. Least squares means of various genotypes for milk traits in Guilan native cows (Bos indicus)

\begin{tabular}{|c|c|c|c|c|c|c|c|}
\hline \multirow[b]{2}{*}{ Leptin genotypes } & \multirow[b]{2}{*}{ No. of cows } & \multicolumn{2}{|c|}{ Milk yield $(\mathrm{kg})$} & \multicolumn{2}{|c|}{ Fat percentage } & \multicolumn{2}{|c|}{ Protein percentage } \\
\hline & & LSM & SE & LSM & SE & LSM & SE \\
\hline AA & 72 & $2.35 \mathrm{c}$ & 0.070 & $3.52 \mathrm{a}$ & 0.046 & $3.35 \mathrm{a}$ & 0.040 \\
\hline$A B$ & 205 & $3.52 \mathrm{a}$ & 0.043 & $3.24 \mathrm{~b}$ & 0.028 & $3.18^{b}$ & 0.024 \\
\hline BB & 113 & $2.83 \mathrm{~b}$ & 0.051 & $3.33 \mathrm{~b}$ & 0.033 & $3.31 \mathrm{a}$ & 0.039 \\
\hline
\end{tabular}

abc Values with different superscripts in each column are different, $(P<0.01)$; LSM= Least squares mean; $S E=S t a n d a r d ~ e r r o r$. 
polimorfismos del gen leptina y la producción y composición de leche, balance energético, consumo de alimento y fertilidad en novillas Holstein; las novillas con el genotipo Sau3AI$A B$ produjeron $1.32 \mathrm{~kg} /$ día más leche, y consumieron $0.73 \mathrm{~kg} /$ día más alimento en comparación con el genotipo Sau3AI-AA. Además, estas novillas con genotipo $A B$ tuvieron mejor fertilidad que el genotipo $A A^{(6)}$. Así mismo se informó de los efectos positivos del genotipo TT versus genotipo $\mathrm{CC}$ en el exón 2 del gen leptina con mayor producción diaria de leche (1.5 kg/día), especialmente en el inicio de la lactancia ( $2.44 \mathrm{~kg} / \mathrm{día}$ ). En contraste, Buchanan et $a /(8)$ no encontraron ningún efecto significativo sobre los porcentajes de proteína o grasa de leche en todo el periodo de la lactación(8). En una revisión en vacas Holstein de Irán se informó diferencia significativa entre genotipos Sau3AI-AB y Sau3AI-AA para características de producción de leche a 305 días y comportamiento reproductivo $(P<0.05)$; y también se demostró que el alelo RFLP B puede producir más leche a 305 días, con una tendencia a mejorar el comportamiento reproductivo(22).

Adicionalmente, el polimorfismo de $\mathrm{HphI}$ en el exón 3 tuvo efecto significativo sobre la producción leche y la proteína(9). EI polimorfismo en el exón 3 del gen leptina se examinó en vacas Holstein y se expresó que consideraba el polimorfismo significativamente asociado con la producción de leche; por lo tanto, se indicó que la mayor y la menor producción de leche se relacionaron con el genotipo GG (BB en este estudio) y genotipo $A A$, respectivamente $(23)$. Se encontró que el polimorfismo Lep-Sau3AI en el intrón 2 se asocia con la grasa de la leche; en la población evaluada, los animales con genotipo AA tuvieron menor producción de grasa de leche que el genotipo $A B(10)$. Variación en la región exónica de un gen puede conducir a cambios en los aminoácidos que alteran la proteína expresada, y aunque la variación intrónica no cambia la secuencia de aminoácidos de la proteína, puede jugar un papel significativo en la manipulación
AA and BB genotypes, respectively, whereas AA genotype had higher fat and protein percentages than the other genotypes $(P<0.01)$. In addition, there was no significant difference between $A B$ and $B B$ genotypes for fat percentage, and between $\mathrm{AA}$ and $\mathrm{BB}$ genotypes for protein percentage $(P>0.05)$.

Results of current study were consistent with the most published reports on the effects of leptin genotypes on productive traits. Consistent with the results of the present study, positive tendencies and associations were demonstrated between different polymorphisms in the leptin gene and milk yield and composition, energy balance, feed intake and fertility in Holstein heifers. As it was reported that heifers with the Sau3AI-AB genotype produced $1.32 \mathrm{~kg} / \mathrm{d}$ more milk and consumed $0.73 \mathrm{~kg} / \mathrm{d}$ more food compared with the Sau3AI-AA genotype. Also, these heifers with $A B$ genotype had better fertility than AA genotype(6). The positive effects of $\pi$ genotype versus CC genotype in exon 2 of the leptin gene with greater test-day milk yield $(1.5 \mathrm{~kg} / \mathrm{d})$, especially in early lactation $(2.44 \mathrm{~kg} / \mathrm{d})$ was reported. In contrast, Buchanan et $a(8)$ published a no significant effect on milk fat or protein percentages over the entire lactation(8). In a review on Iranian Holstein cows significant difference was reported between Sau3AI-AB and Sau3AI-AA genotypes for 305-d milk yield and reproductive performance traits $(P<0.05)$ and also it was demonstrated that the RFLP $B$ allele can yield a higher 305-d milk production with a trend to better reproductive performance(22).

Additionally, the HphI polymorphism in exon 3 had a significant effect on the milk and protein yields(9). The polymorphism in exon 3 of leptin gene was examined in Holstein cows and it was expressed that the considered polymorphism is significantly associated with milk production; therefore, it was stated that the highest and the lowest milk production was related to $G G$ ( $B B$ in this study) and $A A$ genotype, respectively(23). The Lep-Sau3AI polymorphism in intron 2 was revealed that is 
genética o la unión de proteínas reguladoras durante la transcripción, que puede estar relacionada con ventajas económicas.

\section{CONCLUSIONES E IMPLICACIONES}

Ciertas asociaciones significativas encontradas en este estudio pueden apoyar el desarrollo de programas que usan información molecular en los loci del gen leptina para la evaluación genética de animales para producción de leche. Los resultados de investigaciones más recientes sugieren que la ventaja de rendimiento de leche en vacas de genotipo $A B$ podría representar una importante ventaja económica para los productores lecheros. Puede ser debido al acoplamiento genético entre genes de leptina y los genes que se asocian con rasgos de producción. Parecería que la evaluación de varios polimorfismos de genes candidato al mismo tiempo sobre las características funcionales puede demostrar una mejor comprensión del impacto de estos genes.

\section{AGRADECIMIENTOS}

Este trabajo fue apoyado financieramente por la Universidad de Guilán, Irán.

\section{LITERATURA CITADA}

1. Gelderman $\mathrm{H}$. Investigations on inheritance of quantitative characters in animals by gene markers. Methods Theor Appl Gen 1997;46:319-330.

2. Sadeghi M, Moradi Shahr Babak M, Rahimi G, Nejati Javaremi A. Effect of leptin gene polymorphism on the breeding value of milk production traits in Iranian Holstein. Inter J Anim Bios 2008;2(7):999-1002.

3. Ramsay TG, Cranwell PD. A review - Leptin: A regulator of feed intake and physiology in swine. Proc Seventh Biennial Conf Australasian Pig Sci Assoc (APSA), Adelaide, Australia. 1999:157-170.

4. Block SS, Butler WR, Ehrhardt RA, Bell AW, van Amburgh $M E$, Boisclair YR. Decreased concentration of plasma leptin in periparturient dairy cows is caused by negative energy balance. J Endocrinol 2001;171:339-348.

5. Stone RT, Kappes SM, Beattie CW. The bovine homolog of the obese gene maps to chromosome 4. Mamm Genome 1996;(7):399-400. associated with milk fat; in evaluated population, animals with $A A$ genotype had lower milk fat production than $A B$ genotype(10). Variation in the exonic region of a gene may lead to changes in amino acids which alter the expressed protein, and although intronic variation does not change the amino acid sequence of the protein it may play a significant role in gene splicing or the binding of regulatory proteins during transcription that can be related to economic traits.

\section{CONCLUSIONS AND IMPLICATIONS}

Certain significant associations found in this study can support the development of breeding programs that use molecular information on the leptin gene loci for the genetic evaluation of animals for milk traits. The most recent research results suggested that the milk yield advantage in cows for $A B$ genotype could represent a major economic advantage to dairy producers. It can be due to genetic linkage between leptin gene and genes which are associated with production traits. As a suggestion, it seems that evaluation of several candidate genes polymorphisms at the same time on functional traits can show a better understanding of the impact of these genes.

\section{ACKNOWLEDGMENTS}

This work was financially supported by the University of Guilan, Iran.

End of english version

6. Liefers SC, Te Pas MF, Veerkamp RF, Van der Lende T. Associations between leptin gene polymorphisms and production, live weight, energy balance, feed intake and fertility in Holstein heifers. J Dairy Sci 2002;85(6):16331638.

7. Silva LF, VandeHaar MJ, Weber Nielsen MS, Smith GW. Evidence for a local effect of leptin in bovine mammary gland. J Dairy Sci 2002;85:3277-3286. 
Mojtaba Rezaei, et al. / Rev Mex Cienc Pecu 2015;6(1):15-24

8. Buchanan FC, Van Kessel AG, Waldner C, Christensen DA, Laarveld B, Schmutz SM. Hot topic: An association between a leptin single nucleotide polymorphism and milk and protein yield. J Dairy Sci 2003;86(10):3164-3166.

9. Madeja Z, Adamowicz T, Chmurzynska A, Jankowski T, Melonek J, Switonski M, Strabel T. Short communication: effect of leptin gene polymorphisms on breeding value for milk production traits. J Dairy Sci 2004;87:3925-3927.

10. Javanmard A, Khaledi K, Asadzadeh N, Solimanifarjam AR. Detection of polymorphisms in the bovine leptin (Lep) gene: Association of single nucleotide polymorphism with breeding value of milk traits in Iranian Holstein cattle. J Mol Genet 2010;2:10-14.

11. Buchanan FC, Fitzsimmons $C$, Van Kessel AG, Thue TD, Winkelman-Sim C, Schmutz SM. Association of a missense mutation in the bovine leptin gene with carcass fat content and leptin mRNA levels. Genet Sel Evol 2002;34:105-116.

12. Kononoff PJ, Deobald HM, Stewart EL, Laycock AD, Marquess FL. The effect of a leptin single nucleotide polymorphism on quality grade, yield grade and carcass weight of beef cattle. J Anim Sci 2005;83:927-932.

13. Schenkel FS, Miller SP, Ye X, Moore SS, Nkrumah JD, Li C, Yu J, Mandell IB, Wilton JW, Williams JL. Association of single nucleotide polymorphisms in the leptin gene with carcass and meat quality traits of beef cattle. J Anim Sci 2005;83:2009-2020.

14. Liefers SC, Veerkamp RF, Te pas MF, Chilliard Y, Van der lende T. Genetics and physiology of leptin in periparturient dairy cows. Domest Anim Endocrin 2005;29:227-238.

15. Nkrumah JD, Li C, Yu J, Hansen C, Keisler DH, Moore SS. Polymorphisms in the bovine leptin promoter associated with serum leptin concentration, growth, feed intake, feeding behavior and measures of carcass merit. J Anim Sci 2005;83(1):20-28.

16. Javanrouh A, Banabazi MH, Esmaeilkhanian S, Amirinia $\mathrm{C}$, Seyedabadi HR, Emrani H. Optimization on salting out method for DNA extraction from animal and poultry blood cells. 57th Ann Meet European Assoc Anim Prod. September 17-20, 2006; Antalya, Turkey; 2006;101.

17. Lien $S$, Sundvold $H$, Klungland $H$, Vage DI. Two novel polymorphisms in the bovine obesity gene (OBS). Anim Genet 1997;28:45.

18. Yeh F, Yang R, Boyle T, Ye Z, Mao JX. Pop Gene, the userfriendly computer freeware for the analysis of genetic variation among and within populations using co-dominant and dominant markers. Molecular Biology and Biotechnology Center, University of Alberta. 2000.

19. SAS. 2004. SAS user's guide: Statistics (Version 9.1 Ed.). SAS Inst. Inc., Cary, N.C. USA.

20. Choudhary V, Kumar P, Bhattacharya TK, Bhushan B, Sharma A. DNA polymorphism of leptin gene in Bos indicus and Bos taurus cattle. Genet Mol Biol 2005;28(4):740-742.

21. Bourdon RM. Understanding Animal Breeding. 2nd ed. New Jersey, USA: Prentice-Hall PTR; 2000.

22. Heravi Moussavi AR, Ahouei M, Nassiry M, Javadmanesh A. Association of leptin polymorphism with production, reproduction and plasma glucose level in Iranian Holstein cows. Asian Austral J Anim 2006;627-631.

23. Nazari M, Rostamzadeh J, Rashidi A, Azizi O, Karimi Kurdistani Z. Evaluation of leptin gene polymorphism and its association with milk traits in Holstein cows [abstract]. Iranian Congr Anim Sci. Esfahan Industrial University, Iran. 2012. 